\title{
Identifying Key Criteria for Quality Assessment of Landscape Architecture Projects
}

\author{
Gintaras Stauskis*, Vilnius Gediminas Technical University, Vilnius, Lithuania
}

\begin{abstract}
- the question of quality of modified landscape is critical for the client and the users and depends on the quality of projects. After theoretical and empirical research, the paper proposes the framework for quality assessment criteria and corresponding indicators for assessing landscape architecture projects. By thorough analysis of the recent international research and design and implementation practices in Lithuania, the paper gives the flexible and universal set of environmental, socio-economic, and aesthetic quality criteria and relevant indicators in the context of sustainable performance.
\end{abstract}

Keywords - aesthetics, landscape architecture, project, quality assessment, sustainability.

\section{Background And Scope}

In recent years, cities develop and implement numerous projects for parks and squares, urban open spaces, cultural landscape, and infrastructure landscape. Usually these landscape architecture projects go through different type of public procurement, contests or commissioning that include careful legal and professional scrutiny, public presentations, and discussions. The process of evaluating different versions and proposals of projects is usually quite complicated, depend on subjective judgements of different professionals and reviewers and juries, that run under varying and often doubtful quality criteria. The lack of clear, professionally correct and flexible system for quality assessment often leads to low quality of landscape architecture projects and consequently - to poor urban spaces. Therefore, there is an urgent need for a set of key criteria and detailed indicators for assessing the quality of landscape architecture projects.

The analysis of recent research and criticism of landscape architecture projects in Lithuania shows that the guiding principles for quality assessment of projects for landscape modification go in line with the sustainability goals. Aiming to draft the quality assessment framework for landscape architecture projects the initial question is if quality equivalent to sustainability. As a recent global paradigm, sustainability is covering all but few aspects of our life, built environment and landscape, including projects and their performance. From the architecture and landscape architecture perspective, one may doubt if sustainability goals fully cover creativity and aesthetic values of manmade environment - urban landscape. We may admit that the quality of built environment is represented by the assessed sustainability in a sense that encompasses aesthetic value. By analysing the recent international research findings and landscape design projects in Lithuania the paper aims to outline the concise list of universally applicable key criteria and relevant indicators for the quality assessment of landscape architecture projects in the context of their sustainable performance.

\section{Literature Review}

The scene for sustainability combines the pattern and the process approaches to landscape development proposals, as researchers conclude [1]. There is abundance of indicators used in different kind of environmental studies to describe sustainability; therefore, it is essential to set the framework for their selection and prioritising [2]. The authors investigate multiple ways towards landscape sustainability outlining the cultural dimension of biodiversity, ecosystem services and human wellbeing [3]. Researchers of ecosystem services and human wellbeing identify landscape sustainability as capacity of a landscape to provide consistent, landscape-specific ecosystem services that are essential for maintaining and improving human well-being [4]. Landscape sustainability is a hot topic in research since the $20^{\text {th }}$ century. Multiple bodies research this field and present the most detailed description of landscape analysis with the emphasis on master planning and site design [5].

Environmental sustainability research is a central topic. Global community of researchers in sustainability of the built environment in the last 15 years demonstrate the exponentially growing attention to the green infrastructure problems, as judged from the number of cited publications in Web of Science [6]. Correlation of ecosystems quality with landscape patterns is an important question for optimising urban green space use [7]. While analysing the urban landscape operation, the results of the study allow offering new ecosystem capabilities by regulating urban expansion and adding more forestland in the existing green space. Discussing the use of indicators for describing environmental sustainability researchers point out that a key question is the selection, interpretation and use of numerous available indicators, as stated by Moldan et al. [8].

Economic quality of landscape architecture projects is analysed from several overlapping perspectives. Economic benefits are assessed by the evidence-based design anchored in quantitative performance assessment of landscape design [9]. The results obtained by the principal component analysis and factor analysis methods revealed that the specific character and unique landform of landscape can be quantitatively described to underline its specific differences from other nearby settlements [10]. As stated by the international group of researchers, analysis of key factors for environmental sustainability reflecting on the traditional architecture reveal that the priority factor 
is creating engagement between buildings and other urban and natural systems as landscape [11].

Essential feature of landscape performance is its social quality that naturally intertwines with economic aspects. Landscape performance benefits assessment of 58 high profile landscape design projects [12] suggests to account for social benefits that landscape design projects are going to bring and check that in a post-occupancy evaluation (POE). Research lists several social performance indicators such as public health, education, noise, food, and scenic values; in addition, adequate methods such as observation, survey, interview, and quantitative assessment are suggested for data harvesting [12]. The best way to analyse landscape assessment criteria is in conjunction with urban design quality aiming to optimise interaction between these two interwoven domains [13].

Aesthetic touch is basic cultural phenomenon that turns regular natural environment into landscape as perceived by people. The study suggests the list of cultural criteria reflecting the psychology (landscape appreciation) and physiognomy (landscape assessment, diversity, coherence, continuity) of the spectator for quality assessment [14]. While focusing on the content and design of the outdoor environment researchers suggest using the semantic environment descriptors approach [15]. Dimensions of pleasantness, complexity, unity, enclosedness, affection, and originality may reflect on the assessed qualities of the landscape; to assess visually the urban greenery, researchers use the Floor Green View Index for quantifying visual amenity of urban vegetation [16]. By using photo-based questionnaires, the authors give recommendations for the forest road planning and simultaneously enhancing the protection and sustainability of the ecosystem [17]. By assessing visual impact of buildings on rural landscape, researchers draw special attention to the façade colour that affects optical integration of buildings into the landscape [18]. The paper by Montero-Parejo also drew the visual integrity (visual continuity, compatible contrast) as one of valuable aesthetic criterion for landscape assessment (18). Based on previous research analysis coherence, complexity, legibility and mystery indicators explain the most complex and intriguing aesthetical perception criteria [13]. By listing the means of landscape visual composition, landscape geographers outline the aspects of proportion, scale, rhythm, balance, and colouristic harmony and identify indicators of vertical dispersion, horizontal dispersion, and dominants for describing landscape compositional value [19]. The research that summarises several perception theories outlines eleven indicators and selects seven of them for a pilot study on landscape perception: mystery, legibility, coherence, stewardship, naturalness, openness, and complexity [20]. While analysing landscape quality components researchers emphasise such intangible cultural factors as folk customs, inheritance of folk art, etc. [10]

Sustainable performance and operation of a project is one of its key aspects. Analysing sustainability of an urban district requires more data processing than that for a single building taken in isolation from the processes in its surroundings. This allows establishing a real-time link between the actions taken in the urban area and the indicators representing certain aspects of sustainability [21]. Good assessment of horticultural site specifics such as local plants material, soil features, water availability, and other make the basis for a good landscape design that often starts with site remediation, water flow, and soil rehabilitation conclude Bassuk \& Trowbridge [22]. Therefore, the essential role of sustainable landscape design is to keep and enhance the present quality of the place by adding to it from environmental, socio-economic and aesthetic perspectives [23]. While formulating the criteria for sustainable landscape quality, researchers identify several groups of criteria and suggest a checklist-type assessment method [14]. While assessing the visual quality of landscape as one of its aesthetic criteria, people of different national origin, professional and cultural experience deliver different results to the same landscape [24].

The research analysis clearly identifies environmental, social, economic, aesthetic, and operational groups of quality assessment criteria (Fig. 5).

\section{Review of Projects}

In order to extract the quality criteria referred to by the professionals and the public in meetings and discussions, three landscape architecture projects and one infrastructure landscape project in Vilnius City is analysed. We selected one park project, one plaza project, one small square project, and one infrastructure project. All these projects were prepared for interventions in urban landscape in recent years (2016-2020); they all were reviewed by professionals and discussed with public (see Table I).

Planning for conservation and refurbishment of Reformation Garden started a decade ago, and the first versions of design projects attracted attention of professionals and general public [25]. Initially established as the Calvinist's confession cemetery in 1639, the place later turned into an urban green space. In 1980, the place was transformed into a monumental square for Soviet soldiers by flattening the sloped terrain, demolishing the chapel and installing a huge monument that was removed in 1992. Citizens used the garden for transit and recreation, while several conservation project versions were drafted in 2010-2016, and the final one - by Jurga Večerskyte in 2019. General public and professionals called for minimalistic transformations of the existing state, preservation of abundant trees and representation of multiple cultural layers. Conservation work started in 2018 and is going on along with continuing archeologic investigations and small project adjustments (Fig. 1).

It took more than 30 years before Lukiškių Plaza acquired its recent face after restoration of independence in Lithuania in 1990. Former Dominican Convent Garden in the late $18^{\text {th }}$ century, market place in the $19^{\text {th }}$ century, court square until WW2, and Lenin square until 1990, the place has gone through many periods of development and stages of public use. Several contests have rendered different refurbishment proposals, while public expectations included memorial, representation, recreation, transit, amusement, and some other uses [26]. The implemented project represents the blend of modern plaza and recreation park (Fig. 2). 


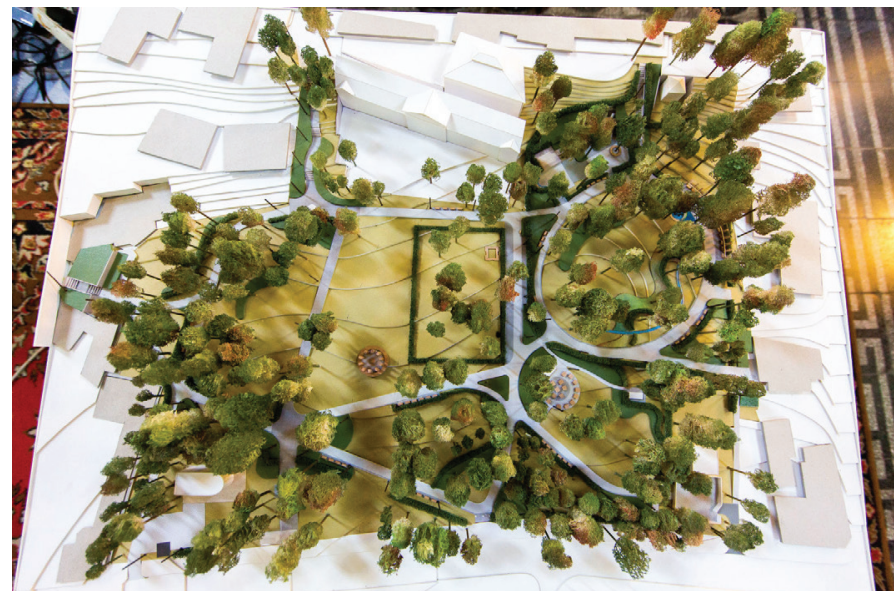

Fig. 1. Conservation project of the Reformation Garden, 2020 [31].

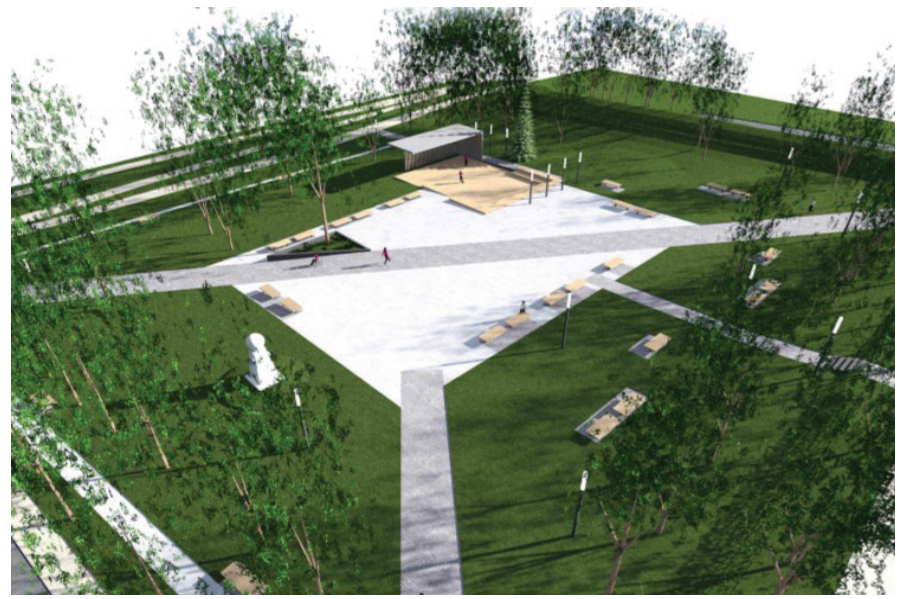

Fig. 3. Project of Balsio square in Vilnius City, 2020 [33].

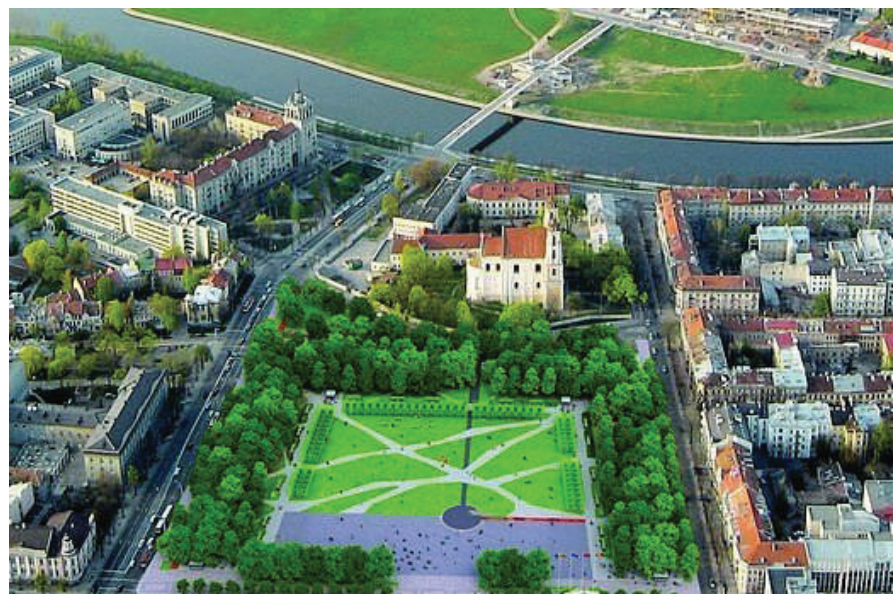

Fig. 2. Lukiškių plaza project in Vilnius City, 2018 [32].

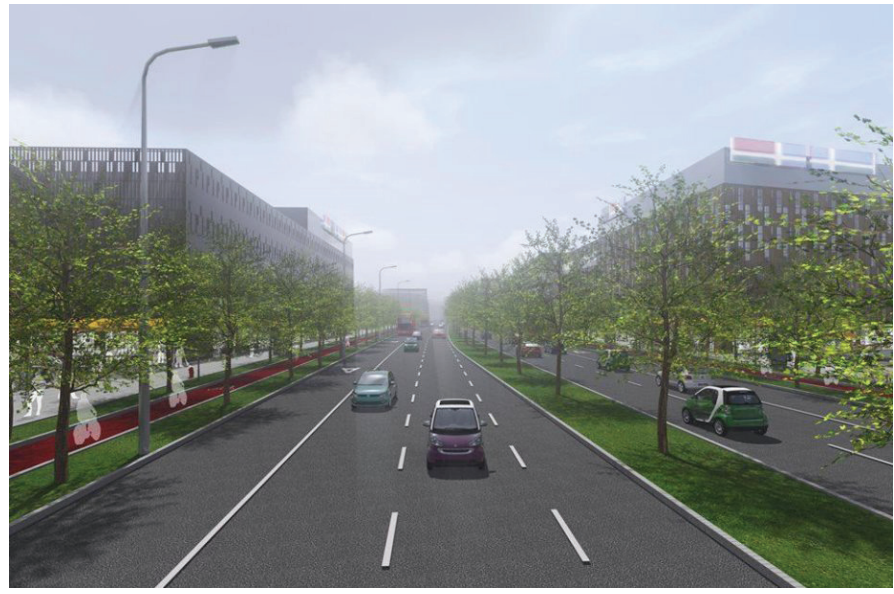

Fig. 4. The Northern Street project in Vilnius City, 2018 [34].

TABLE I

Quality Criteria and Indicators Listed for the Analysed Projects (Figs. 1-4) [Author of the Article]

\begin{tabular}{|c|c|c|c|c|c|}
\hline $\begin{array}{l}\text { Criteria and } \\
\text { addressed aspects }\end{array}$ & Environmental & Social & Economic & Aesthetic & $\begin{array}{l}\text { Operational } \\
\text { performance }\end{array}$ \\
\hline Project title & 1 & 2 & 3 & 4 & 5 \\
\hline $\begin{array}{l}\text { 1. Reformation } \\
\text { Garden }\end{array}$ & $\begin{array}{l}\text { Biodiversity increase, } \\
\text { protection of all trees, } \\
\text { relief restoration }\end{array}$ & $\begin{array}{l}\text { Increased safety, heritage } \\
\text { activation, movement comfort }\end{array}$ & $\begin{array}{l}\text { EU funding, municipal } \\
\text { funding, monument } \\
\text { funded by private } \\
\text { donors }\end{array}$ & $\begin{array}{l}\text { Reformation memorial, } \\
\text { method of fragmental } \\
\text { conservation suggested }\end{array}$ & $\begin{array}{l}\text { No optimised } \\
\text { maintenance plan }\end{array}$ \\
\hline 2. Lukiškių Plaza & $\begin{array}{l}\text { Preservation and } \\
\text { increasing of green } \\
\text { space, new trees added, } \\
\text { heat islands on hard } \\
\text { pavements }\end{array}$ & $\begin{array}{l}\text { Contradictions regarding the } \\
\text { new memorial, combination of } \\
\text { recreation and representation } \\
\text { uses }\end{array}$ & $\begin{array}{l}\text { No pavilions and } \\
\text { underground parking, } \\
\text { state and municipality } \\
\text { co-financed }\end{array}$ & $\begin{array}{l}\text { Minimal intervention } \\
\text { and technical upgrade, } \\
\text { spatial integration, park } \\
\text { blended with plaza, tree } \\
\text { as a planning symbol }\end{array}$ & $\begin{array}{l}\text { No optimised } \\
\text { maintenance plan, big } \\
\text { operation costs for } \\
\text { cropped trees, }\end{array}$ \\
\hline 3. Balsio Square & $\begin{array}{l}\text { Keeping all trees, visual } \\
\text { connection with the } \\
\text { river space, minimal } \\
\text { hard pavements, plants } \\
\text { for pollution mitigation }\end{array}$ & $\begin{array}{l}\text { Ensuring transit and safety, } \\
\text { multiple use (including } \\
\text { cultural events), transit and } \\
\text { recreation, initiated by city } \\
\text { musicians' community }\end{array}$ & $\begin{array}{l}\text { Funded by municipality, } \\
\text { looking for central } \\
\text { government support }\end{array}$ & $\begin{array}{l}\text { Minimal intervention, } \\
\text { regular plan formalising } \\
\text { present state, spatial } \\
\text { integrity, cultural signs } \\
\text { included }\end{array}$ & $\begin{array}{l}\text { No optimised } \\
\text { maintenance plan, poor } \\
\text { present maintenance }\end{array}$ \\
\hline 4. Northern Street & $\begin{array}{l}\text { Existing trees to be } \\
\text { cut, new trees planted, } \\
\text { green space reduced, no } \\
\text { SUDS, additional noise } \\
\text { and pollution source }\end{array}$ & $\begin{array}{l}\text { Additional comfort for drivers, } \\
\text { obstructed pedestrian mobility } \\
\text { and recreation between urban } \\
\text { districts }\end{array}$ & $\begin{array}{l}\text { EU and national funding } \\
\text { EUR } 300 \text { million for } \\
3 \mathrm{~km} \text { interval }\end{array}$ & $\begin{array}{l}\text { Conventional } \\
\text { technogenic aesthetics, } \\
\text { regular plant rows }\end{array}$ & $\begin{array}{l}\text { No optimised } \\
\text { management plan, } \\
\text { additional operation } \\
\text { costs for the city }\end{array}$ \\
\hline
\end{tabular}


For many years, this street corner in the quiet Žvėrynas (the Zoo) district was a comfortable pedestrian cut-off overgrown with limes and maples, hedges, and other spontaneous self-grow. The musicians' community has initiated a project, which probably inspired its design: the project includes a pavilion with a performance stage and amphitheatric terrace for the listeners or just by-passers, all suspended in a vast green space decorated with modest sculptures [27]. While the designer publicly presented the project sketches in 2016, the proposals for a clear zoning, spatial link to the Neris River, respect for the "cut-off" users, and certainly keeping all self-grow greenery came in and were to a certain extent respected in the final design that was completed in 2020 (Fig. 3).

The Northern Street project (2016-2020) for implementing the transversal connection between the main motorways in the North of Vilnius City is drafted following the mobility concept of several city master plans from the mid- $20^{\text {th }}$ century. Currently, the place is a spontaneous grove used by the residents of adjacent urban districts for recreation. The wide six-lane street looks promising for daily drivers but quite doubtful from the perspective of sustainable urban mobility planning (Fig. 4). New commercial development will rise in the adjacent plots [28].

\section{Methodology}

As the paper aims to deliver the key indicators for assessing the quality of a landscape architecture project, the method covers analysis of recent research and all professional landscape architecture projects and gives the opportunity to add weight to different aspects. There are four main domains of projects for the urban environment analysed, designed, and realised under the leadership of landscape architects if classified by the object of intervention (Fig. 5). The landscape planning or design project has the strategic goal to draft the version for future development of a park or square, urban open space, infrastructure or cultural landscape. Parks and squares, urban open spaces, and cultural landscapes are common areas for landscape architect's professional engagement in Lithuania. Still, their involvement in infrastructure projects that are at the forefront of sustainable urban development is still scarce (Fig. 6).

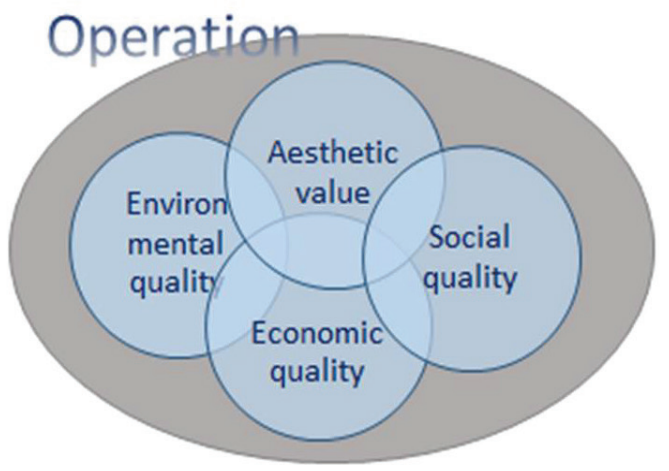

Fig. 5. Thematic domains of landscape architecture project quality criteria [Figure: G.Stauskis].

Projects that we do for improving urban landscape performance aim to make them more attractive and loved by people. Therefore, it is essential to understand the mechanism that drives human environmental preference. Study of physical attributes, land cover types, information variables, and perception variables showed that only the latter rendered significant predictive power, and only mystery had some predictive potential in the information domain [29] (Table II).

TABLE II

Environmental Preferences in Four Domains of Predictors [29]

\begin{tabular}{|l|l|l|l|}
\hline No. & Domain & Attribute & $\begin{array}{l}\text { Predictor for } \\
\text { particular } \\
\text { landscape }\end{array}$ \\
\hline 1. & $\begin{array}{l}\text { Physical } \\
\text { attributes }\end{array}$ & $\begin{array}{l}\text { Land form: slope, } \\
\text { edge, spatial }\end{array}$ & Not significant \\
\hline 2. & Land cover & $\begin{array}{l}\text { Naturalism, } \\
\text { compatibility, } \\
\text { contrast, variety }\end{array}$ & $\begin{array}{l}\text { Significant basis } \\
\text { for preference } \\
\text { prediction }\end{array}$ \\
\hline 3. & $\begin{array}{l}\text { Information } \\
\text { variables }\end{array}$ & $\begin{array}{l}\text { Understanding, } \\
\text { coherence, legibility, } \\
\text { mystery }\end{array}$ & $\begin{array}{l}\text { Lowest in } \\
\text { variance } \\
\text { prediction }\end{array}$ \\
\hline 4. & $\begin{array}{l}\text { Perception } \\
\text { variables }\end{array}$ & $\begin{array}{l}\text { Openness, } \\
\text { smoothness, } \\
\text { locomotion }\end{array}$ & Most powerful \\
\hline
\end{tabular}
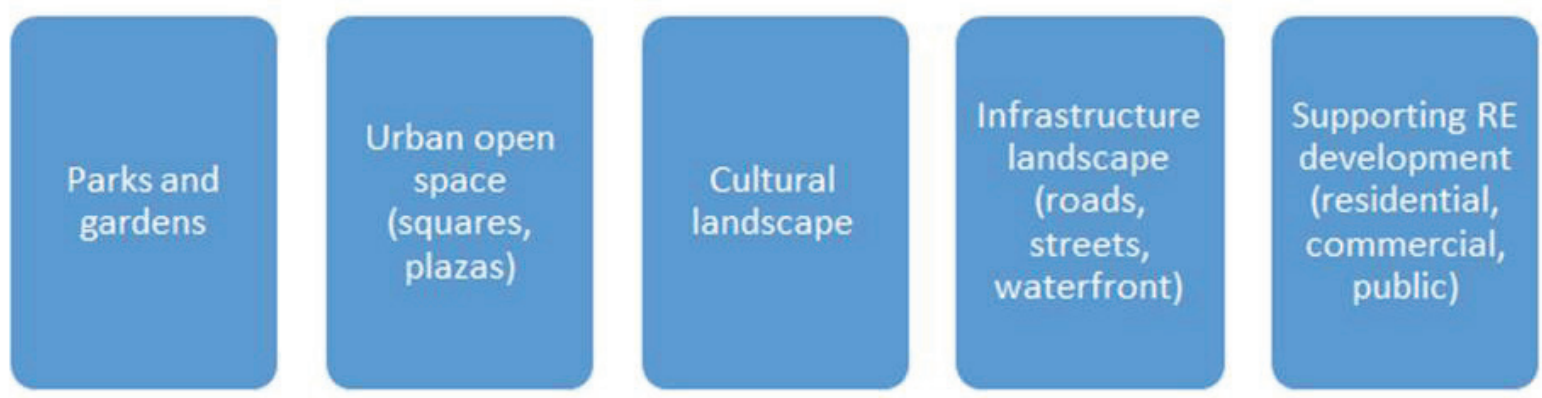

Fig. 6. Domains of urban environment addressed by landscape architecture projects [Figure: G.Stauskis]. 
The environmental risks and dangers of the late $20^{\text {th }}$ century have triggered the "safety" switch of human motivation as laid down in Maslow's motivation theory from 1943 [30] (Fig. 7). The realisation of persons' higher aspirations for social inclusion and self-esteem may be realised after the primary need for "environmental" and other safety is ensured.

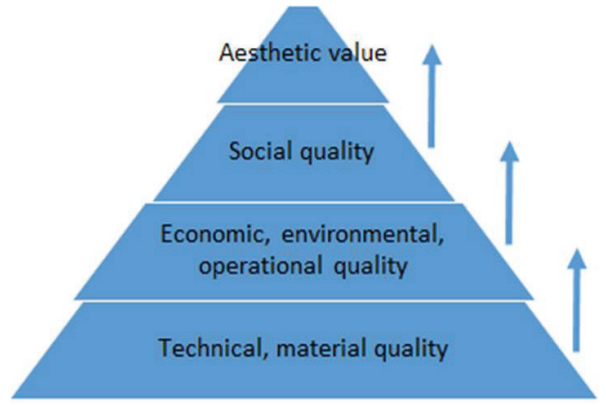

Fig. 7. Hierarchy of the outlined qualities and values [Figure: G.Stauskis].
After collecting the pool of indicators for environmental, socio-economic qualities, and aesthetical values in the operations and performance shield, we structure them into the following criteria groups (Table III).

\section{Results and Discussion}

The framework of key quality criteria that is the main goal of this paper allows having a complex objective assessment of a landscape architecture project. It reflects the globally accepted sustainability goals for the built environment in general and for landscape architecture domain in particular, as was concluded from the recent research; and more, it encompasses the practical issues and challenges that arise from the analysed projects (Table I). The list of 33 indicators makes it possible to assess all quality criteria, still, it may extend with additional indicators that are detailed. The developed framework of quality criteria and in-

TABLE III

Key Quality Criteria and Indicators for Assessing Landscape Architecture Projects [Author of the Article]

\begin{tabular}{|c|c|c|c|}
\hline Group & Criteria & Indicators & Weight, score \\
\hline $\begin{array}{l}\text { 1. Aesthetic value } \\
\mathrm{k} 1=0.20\end{array}$ & $\begin{array}{l}\text { 1-1 Authentic (genius loci) } \\
1-2 \text { Individual } \\
1-3 \text { Representative } \\
1-4 \text { Natural } \\
1-5 \text { Contextual } \\
1-6 \text { Understandable } \\
1-7 \text { Perceptional } \\
1-8 \text { Intangible cultural values }\end{array}$ & $\begin{array}{l}\text { Local, regional character } \\
\text { Diverse, outstanding } \\
\text { Common of place, time } \\
\text { Compatible, varying, contrasting } \\
\text { Visual integrity, continuity } \\
\text { Coherent, legible, mysterious } \\
\text { Open, smooth, locomotion } \\
\text { Activated heritage and folk customs }\end{array}$ & $1-10$ \\
\hline \multirow[t]{3}{*}{$\begin{array}{l}\text { 2. Environmental } \\
\text { quality } \mathrm{k} 2=0.20\end{array}$} & $\begin{array}{l}\text { 2-1 Climate change mitigation } \\
2-2 \text { Water availability and quality }\end{array}$ & $\begin{array}{l}\text { GHG control (zero } \mathrm{CO}_{2} \text { goal) } \\
\text { SUDS, } \%\end{array}$ & $1-10$ \\
\hline & $\begin{array}{l}\text { 2-3 Air quality } \\
\text { 2-4 Plants and vegetation } \\
\text { 2-5 Ecosystem stability } \\
\text { 2-6 Life cycle assessment }\end{array}$ & $\begin{array}{l}\text { Dust, ppm } \\
\text { Local plants, \% } \\
\text { Afforestation, \% } \\
\text { EIA optimisation }\end{array}$ & \\
\hline & 2-7 Land and soil & Relief protection, erosion control & \\
\hline $\begin{array}{l}\text { 3. Social-economic } \\
\text { quality } \\
\mathrm{k} 3^{*}=0.20 \mathrm{~s}+0.20 \mathrm{e}\end{array}$ & $\begin{array}{l}\text { 3-1s Health and personal safety } \\
\text { 3-2s Public security } \\
\text { 3-3s Public participation } \\
\text { 3-4s Universal design for all } \\
\text { 3-5s Inclusive placemaking } \\
\text { 3-6s Use of non-renewable resources } \\
\text { 3-7s New employment } \\
\text { 3-8e Investment efficiency } \\
\text { 3-9e NPV flow in time } \\
\text { 3-10e Fossil energy EROI } \\
\text { 3-11e Local materials and resources } \\
\text { 3-12e Food, energy, fuels security } \\
\text { 3-13e Efficient mobility }\end{array}$ & $\begin{array}{l}\text { No hazardous materials } \\
\text { Crime prevention } \\
\text { Inclusive for community } \\
\text { Meeting UD code } \\
\text { Urban open space increase } \\
\text { Petrol use per capita } \\
\text { SME employment places } \\
\text { ROI years } \\
\text { Benefits minus costs, Eur } \\
\text { Fossil energy, MJ/ useful energy } \\
\text { Imported materials/all materials } \\
\text { Price change / year } \\
\text { SUMP }\end{array}$ & $1-10$ \\
\hline $\begin{array}{l}\text { 4. Operational } \\
\text { quality } \\
\mathrm{k} 4=0.20\end{array}$ & $\begin{array}{l}\text { 4-1 Lifecycle costs } \\
\text { 4-2 Landscape management plan } \\
\text { 4-3 PPP dialogue for operation } \\
\text { 4-4 Resources optimisation plan (watering, mowing, cleaning, repair) } \\
\text { 4-5 Operation risks management plan } \\
\text { 4-6 Wellbeing promotion plan } \\
\text { 4-7 In-use assessment }\end{array}$ & $\begin{array}{l}\text { ROI years } \\
\text { Yes }- \text { no } \\
\text { Yes }- \text { no } \\
\text { Yes }- \text { no } \\
\text { Yes }- \text { no } \\
\text { Yes }- \text { no } \\
\text { Yes }- \text { no }\end{array}$ & $1-10$ \\
\hline $4 \mathrm{k}=1.0$ & 33 & Data & 50 \\
\hline
\end{tabular}

Source: own elaboration. $3^{*}$ - double (social and economic) nature of the criterion. Abbreviations: ppm - particles per million, UD - universal design, SUDS - sustainable urban drain system, ROI - return on investment, NPV - net present value, EIA - environmental impact assessment, EROI - environmental return on investment, 3(s) - social, 3(e) - economic, PPP - public and private partnership, SUMP - sustainable urban mobility planning, SME - small and medium enterprises, GHG - greenhouse gas, MJ - mega joule, energy. 
dicators is usable by multiple private, public or NGO stakeholders' groups for different types of projects as listed in Table IV.

$$
\text { TABLE IV }
$$

Potential Users of the Quality Assessment Method [Author of the Article]

\begin{tabular}{|c|c|c|}
\hline Users & \multirow{9}{*}{$\begin{array}{l}\text { The process of complex } \\
\text { quality assessment of } \\
\text { the presented landscape } \\
\text { architecture projects } \\
\text { for parks and gardens, } \\
\text { urban open spaces, } \\
\text { cultural landscapes, } \\
\text { infrastructure } \\
\text { landscapes, supporting } \\
\text { involvement. }\end{array}$} & Types of projects \\
\hline Municipalities & & $\begin{array}{l}\text { Contest entry } \\
\text { evaluation }\end{array}$ \\
\hline Agencies & & Commissioned projects \\
\hline Ministries & & $\begin{array}{l}\text { Comparing the project } \\
\text { versions }\end{array}$ \\
\hline Communities & & $\begin{array}{l}\text { Preliminary design for } \\
\text { public discussion }\end{array}$ \\
\hline Private developers & & $\begin{array}{l}\text { Technical } \\
\text { documentation }\end{array}$ \\
\hline $\begin{array}{l}\text { Researchers and } \\
\text { academia }\end{array}$ & & As-built project \\
\hline Students and scholars & & $\begin{array}{l}\text { Post-occupancy } \\
\text { evaluation }\end{array}$ \\
\hline $\begin{array}{l}\text { Professional } \\
\text { community }\end{array}$ & & $\begin{array}{l}\text { Sustainability } \\
\text { assessment }\end{array}$ \\
\hline
\end{tabular}

As we see from the summary in Table I, all reviewed landscape architecture projects are solving many challenges from environmental perspective: protecting the existing trees and adding new ones, reducing the amount of hard pavements, respecting the existing or restoring lost relief features. Social aspect lists numerous issues strongly defended by the communities: recreation, movement comfort, and safety integrated with any other uses requested by clients, and generally opposing new memorialisation proposals. The reviewed projects poorly mind economic constrains: usually they rely on the EU, municipal or national funding, no additional income, co-financing or ROI (or EROI) options were analysed. All reviewed projects paid great attention to creating new aesthetic values and building on top of the existing cultural values. Minimalistic trend is prevailing, but some proposals employ decorative, restorative, even eclectic approaches. Operational efficiency aspect is generally missing in all projects, maybe except the Northern Street project, projects address management of the designed facilities even less than formally required; optimisation of operational qualities is practically omitted. It may be summarised that landscape architecture projects and the regular design practice have good aesthetic orientation but evidently lack the sustainability approach. Analysis of projects involving landscape architects in Vilnius City show that they clearly miss numerous sustainability-oriented instruments and applications. Moreover, this is quite different from the quality indicators outlined in the reviewed research where sustainability-oriented goals and concrete solutions dominate over the conventional technogenic practices and regular functionality. Therefore, the developed quality assessment framework with transparent criteria and clear indicators is useful for introducing the missing quality aspects.

The detailed quality criteria and indicators' summary given in Table III from the Motivation Theory perspective show four motivation strata: basic (technical), medium (economic, environ- mental, operational), upper (social), and the highest (aesthetic) as in Fig. 7. It is important to note in this regard that we may advance to the upper and the highest strata qualities and values only after achieving the qualities of the basic and the medium strata.

Analysis of human environmental motivation showed that physical elements of environment are often overestimated in design regarding their power to impress and motivate people, and perception variables like openness, smoothness, and locomotion are often underestimated for the same reason (Table II). Therefore, perception domain with its attributes is an adequate component of aesthetic criteria for assessing landscape architecture design quality and should be taken as a priority for any landscape intervention.

\section{Conclusions}

The performed research is an important step forward to: (a) bring transparency to the process of project quality assessment, to professional discussions and public debates; (b) improve the landscape architecture projects, as this framework can be included in the education curricula and professional development schemes. The main research findings indicate (Table III) that the concise yet flexible set of indicators could be used to assess the quality and value of landscape architecture design from the point of universal quality criteria. Their prioritising and weighing is needed in each particular case. The designers shall treat the high degree of motivation bared by the perception variables jointly with sustainable approach in performing the variety of tasks for designing new or refurbishing the existing parks and gardens, urban open spaces, cultural landscapes, and infrastructure landscapes, also performing assistive landscape architecture role in real estate development projects. The prioritising, assessing, and processing of the outlined criteria and integrative indicators will be tested in the following steps of further research.

\section{REFERENCES}

1. Dale, V. H., Kline, K. L., Parish, E. S., Eichler, S. E. Engaging stakeholders to assess landscape sustainability. Landscape Ecology, Vol. 34 2019, pp. 1199-1218. https://doi.org/10.1007/s10980-019-00848-1

2. Rasmussen, L. V., Bierbaum, R., Oldekop, J. A., Agrawal, A. Bridging the Practitioner-Researcher Divide: Indicators to Track Environmental, Economic, and Sociocultural Sustainability of Agricultural Commodity Production. Glob Environ Chang., Vol. 42, 2017, pp. 33-46. https://doi.org/10.1016/j.gloenvcha.2016.12.001

3. Musacchio L. R. Key concepts and research priorities for landscape sustainability. Landscape Ecology, Vol. 28, 2013, pp. 995-998.

https://doi.org/10.1007/s10980-013-9909-6

4. Wu, J. Landscape Sustainability Science: Ecosystem Services and Human Well-being in Changing Landscapes. Landscape Ecology, Vol. 28, 2013, pp. $999-1023$.

5. Gardner, L., Rogers, S., Sipes, J. L. Oak Ridge National Laboratory: Sustainable Landscapes Initiative 2020. U.S. Department of Energy: Office of Scientific and Technical Information, 2012. https://doi.org/10.2172/1128954

6. Thome, A. M. T., Ceryno, P. S., Scavarda, A., Remmen, A. Sustainable infrastructure: A review and a research agenda. Journal of Environmental Management, Vol. 184, 2016, pp. 143-156. Management, Vol. 184, 2016, pp. 143-156.
http://dx.doi.org/10.1016/j.jenvman.2016.09.080

7. Wang, B., Liu, Zh., Mei, Yu., Li, W. Assessment of Ecosystem Service Quality and Its Correlation with Landscape Patterns in Haidian District, Beijing. International Journal of Environmental Research and Public Health, Vol. 16, 2019, p. 1248. https://doi.org/10.3390/ijerph16071248 
8. Moldan, B., Janouškova, S., Hak, T. How to Understand and Measure Environmental Sustainability: Indicators and Targets. Ecological Indica tors, Vol. 17, 2012, pp. 4-13. https://doi.org/10.1016/j.ecolind.2011.04.033

9. Wang, Zh., Yang, B. Li, Sh., Binder, Ch. Economic Benefits: Metrics an Methods for Landscape Performance Assessment. Sustainability, Vol. 8, No. 424, 2016, pp. 1-12. https://doi.org/10.3390/su8050424.

10. Wen, B., Burley, J. B. Expert Opinion Dimensions of Rural Landscape Quality in Xiangxi, Hunan, China: Principal Component Analysis and Factor Analysis. Sustainability, Vol. 12, 2020, p. 1316

https://doi.org/10.3390/su12041316

11. Mahdiraji, H. A., Arzaghi, S., Stauskis, G., Zavadskas, E. K. A hybrid fuzzy BWM-COPRAS method for analyzing key factors of sustainable architecture // Sustainability. Basel: MDPI AG. eISSN 2071-1050. Vol. 10, Issue 5, art. No. 1626, 2018. pp. 1-26. (Special Issue: Sustainability in Construction Engineering). https://doi.org/10.3390/su10051626.

12. Yang, B., Li, Sh., Binder, Ch. 2016. A Research Frontier in Landscape Architecture: Landscape Performance and Assessment of Social Benefits. Landscape Research, Vol. 41, No. 3, 2015. pp. 314-329. https://doi.org/10.1080/01426397.2015.1077944

13. Deveikienè, V. Methodological guidelines for optimizing the interaction between landscape architecture and urban planning. Landscape Architecture and Art, Vol. 12, No. 12, 2018, pp. 7-21. https://doi.org/10.22616/j.landarchart.2018.12.01

14. Kuiper, J. A Checklist Approach to Evaluate the Contribution of Organic Farms to Landscape Quality. Agriculture, Ecosystems and Environment, No. 77. 2000. pp. 143-156. PII: S0167-8809(99)00099-7.

15. Bengtsson, A., Hägerhäll, C., Englund, J.-E., Grahn, P. Outdoor Environments at Three Nursing Homes: Semantic Environmental Descriptions. Journal of Housing for the Elderly, Vol. 29, No. 1-2, 2015, pp. 53-76. https://doi.org/10.1080/02763893.2014.987863

16. Yu, S., Yu, B., Song, W., Wu, B., Zhou, J., Huang, Y., Wu, J., Zhao, F. Mao, W. View-based Greenery: A Three-dimensional Assessment of City Buildings' Green Visibility Using Floor Green View Index. Landscape and Urban Planning, Vol. 152, 2016. pp. 13-26. http://dx.doi.org/10.1016/j.landurbplan.2016.04.004

17. Karasah, B. A Visual Landscape Assessment of Forest Roads: Case of Kafkasör-Mersivan Route, Artvin. Kastamonu University. Journal of For estry Faculty, Vol. 17, No. 3, 2017, pp. 404-413. IFS 2016, Special Issue. https://doi.org/10.17475/kastorman.285686.

18. Montero-Parejo, M. J., Garcia-Moruno, L., Reyes-Rodriguez, A. M. Hernandez-Blanco, J., Garrido-Velarde, J. Analysis of Facade Color and Cost to Improve Visual Integration of Buildings in the Rural Environment. Sustainability, Vol. 12, No. 3840, 2020, pp. 1-16. https://doi.org/10.3390/su12093840.

19. Kavaliauskas, P. Kraštovaizdžio samprata ir planavimas. Mokomoji knyga. Vilniaus universitetas. 2011, pp. 72-73, 129-130. ISBN 978-609459-004-7.

20. Solehin Fitry Rosley, M., Lamit, H., Rahman, S.R.A. Perceiving the Aesthetic Value of the Rural Landscape through Valid Indicators. Proce dia - Social and Behavioral Sciences 85, 2013, pp. 318-331. https://doi.org/10.1016/j.sbspro.2013.08.362

21. Kuster, C., Hippolyte, J.-L., Rezgui, Y. The UDSA ontology: An Ontology to Support Real Time Urban Sustainability Assessment. Advances in Engineering Software. Vol. 140, 2020. https://doi.org/10.1016/j.advengsoft.2019.102731

22. Bassuk, N., Trowbridge, P. Creating the Urban Eden: Sustainable Landscape Establishment in Theory and Practice. Sustainability and Horticultural Education. Vol. 20 No. 3. 2010. pp. 485-486. https://doi.org/10.21273/HORTTECH.20.3.485

23. American Society of Landscape Architects ASLA. Sustainable Sites Initiative. The Case for Sustainable Landscapes. 2009. 54 p. [online]. Sustainable Sites [cited 27.07.2020]. www.sustainablesites.org

24. Noralizawati, M., Noriah, O., Mohd, H. A. Value of Nature in Life: Landscape Visual Quality Assessment at Rainforest Trail, Penang. Procedia - Social and Behavioral Sciences, No. 50, 2012, pp. 667-674. https://doi.org/10.1016/j.sbspro.2012.08.069

25. Reformatu skveras, 2019 [online, cited 30.07.2020]. http://reformatuskveras.lt/

26. Lukiškiu aikštė. Gedimino pr. Naujamiestis, Vilnius, 2020 [online, cited 30.07.2020]. https://citify.eu/lukiskiu-aikste/

27. E. Balsio skvero rekonstrukcijos projektas: su vardiniais suoliukais ir scena kultūros renginiams, 2020 [online, cited 30.07.2020]. https://vilnius 1t/1t/2020/02/13/e-balsio-skvero-rekonstrukcijos-projektas-su-vardiniais-suoliukais-ir-scena-kulturos-renginiams/

28. Vilniaus Šiaurinès gatvès projektą žada pagaliau išjudinti: statybos - galbū dar šiemet. 2020 [online, cited 31.07.2020]. https://www.15min.lt/gazas/ naujiena/gatve/vilniaus-siaurines-gatves-projekta-zada-pagaliau-isjudinti-statybas-jau-vasara-221-1264078\#

29. Kaplan, R., Kaplan, S., Brown, T. Envvironmental Preference. A Comparison of Four Domains of Predictors. Environment and Behaviour. Vol. 21, No. 5, 1989, pp. 509-530. SAGE Social Science Collections. SAGE Publications Inc.
30. Maslow, A. H. A Theory of Human Motivation. Psychological Review. Vol. 50, 1943, pp. 370-396.

31. The Reformation Garden conservation project. 2020 [online, cited 30.07.2020]. https://s1.15min.1t/images/photos/2018/08/09/original/vilniaus-savivaldybes-parengto-reformatu-skvero-plano-aptarimas-su-jo-kurejais-5b6c65f034d08.jpg

32. Lukiškių plaza project in Vilnius City. 2018 [online, cited 30.07.2020]. https://www.lrt.lt/img/2016/05/12/125399-306040-756x425.jpg

33. Eduardo Balsio square project in Vilnius City. 2020 [online, cited 30.07.2020]. https://vilnius.lt/wp-content/uploads/2020/02/Eduard_Balsio_skver2.jpg

34. The Northern Street project in Vilnius City. 2018 [online, cited 30.07.2020]. https://s2.15 min.1t/static/cache/OTI1eDYxMCw0NzV4NDEyLDYxNjMwNCxvcmlnaW5hbCwsaWO9Mzc2NDM4NiZkYXR1PT IwMTg1MkYwMyUyRjE5LDMyMzY 5 MDk$0 \mathrm{MzY}=/ 29343227$ 1220876294715369_7949022276257579008_n-5aafablee0297.jpg

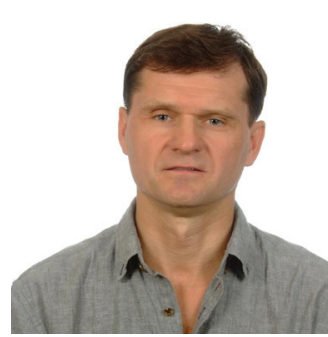

Gintaras Stauskis is an architect and urban designer, he graduated in 1986 . He received a degree of Doctor of $\mathrm{Ph}$. in 1994 and since 2014 has been a Professor with the School of Architecture of Vilnius Gediminas Technical University. He is also Head of the design office JSC A-7G.

He takes part in EU and national research projects and architecture and landscape contests. Recently he participated in the contest for refurbishing Vokiečių Street in Vilnius City. G. Stauskis is a member of the Lithuanian Chamber of Architects, Lithuanian Association of Landscape Architects, a delegate to IFLA, as well as a Board member of the Lithuanian Green Building Council.

Stauskis' scientific interests are interaction of landscape and urbanism, accessibility and sustainability of built environment. See the list of his publications: https://vgtu.academia.edu/GintarasStauskis

\section{Contact Data}

Gintaras Stauskis

Department of Urban Design, Faculty of Architecture, Vilnius Gediminas Technical University.

Address: 1 Trakų Str., 01332, Vilnius, Lithuania 